\title{
Why women empowerment is needed post COVID-19?
}

\author{
Prerna Karulkar ${ }^{1 *}$
}

\section{ABSTRACT}

The dreadful COVID-19 pandemic has brought forth many harsh realities. This has affected men and women differently. As it is, women already suffer the fate of the lesser gender due to the prevalent patriarchal society. The ongoing outbreak has increased this divide. Women face many challenges be it in urban or rural area, middle or low-income group; the issues differ to an extent, but they exist. The roles as defined by the social norms have become more prominent. This paper attempts to study the various consequences of the COVID-19 pandemic on women and men. It provides an assessment as to why women empowerment is the need of the hour and tries to find probable solutions to the pertaining problems. Education and financial independence are two primary ways of empowerment at individual level. As a society, we need to rethink and revamp the values, beliefs, attitudes towards gender norms and predefined roles. We need to make changes at the grass root level to bring in equality. Global social transformation is required in order to weaken the deep-rooted patriarchy.

Keywords: Pandemic, Women Empowerment, Social Norms, Financial Independence, Patriarchal Society, COVID-19

7 he year 2020 has seen the outbreak of novel corona virus which impacted the whole world gravely. This will be remembered as a major global pandemic in the history of pandemics for centuries. The presence of anxiety, depression and stress was evident in the people due to the outbreak and the subsequent lock down (Verma, S., \& Mishra, A., 2020). The impact of corona virus is seen differently on different genders (Lewis, H. 2020). Women are adversely affected throughout the world.

According to the National Mental Survey of India, females are more likely to be more anxious than males (Gururaj et al ,2016). This can be attributed to many factors. Due to the lockdown, everyone faced different challenges. Men faced economic issues and problems to continue with their jobs and technological challenges of working from home. Women had to undergo a lot of new challenges like increased work at home. In any average middle-class Indian household, the working woman gets most of the support from part-time maids, washermen, cooks, gardeners etc. During the lockdown all these people were unable to do their work. As India is a patriarchal society, there is strict demarcation of household chores and all the domestic work is done mostly by the ladies of the house. However, working

\footnotetext{
${ }^{1}$ Student, M.A Clinical Psychology, School of Social Sciences, Devi Ahilya Vishwavidyalaya, Indore, Madhya Pradesh, India *Responding Author

Received: October 10, 2020; Revision Received: November 28, 2020; Accepted: December 22, 2020 (C) 2020, Karulkar P.; licensee IJIP. This is an Open Access Research distributed under the terms of the Creative Commons Attribution License (www.creativecommons.org/licenses/by/2.0), which permits unrestricted use, distribution, and reproduction in any Medium, provided the original work is properly cited.
} 
women had to deal with the dual responsibility of work from home and managing the chores. The unpaid care work at home is done mostly by women throughout the world and due to this corona crisis, this burden has increased manifold (Power, K.,2020). Women were also entrusted with the added responsibility of their children's studies, as children had online classes and their studies too needed full-time supervision and guidance.

\section{Marginalised women}

The women from marginalised communities faced different kinds of problems. They saw economic stress on families as many women who worked as house maids became jobless. Due to the outbreak the young girls were at a greater risk of exploitation, child labour and gender-based violence at home. The girls faced sexual violence from their relatives with whom they had to stay for longer periods. (How will covid 19 affect girls and young women? retrieved from https://plan-international.org/emergencies/covid-19-faqs-girlswomen)

It is usually seen during any other disease outbreak that the work burden on women increases. In a study, the intersections between Covid-19 and gendered burdens are highlighted, particularly in frontline work, unpaid care work and community activities (McLaren, H. J., Wong, K. R., Nguyen, K. N., \& Mahamadachchi, K. N. D. ,2020).

The ongoing COVID crisis has also given rise to already widespread evil of domestic violence in the society. The National Commission for Women (NCW) India in early April 2020 reported a large spike in such cases since lockdown was imposed. This twofold increase in sexual assaults and domestic violence has pushed NCW to announce Mental Health Helplines for those witnessing any form of domestic violence. It also noticed police apathy towards crime against women. (Chandra J. 2020. NCW Launches Domestic Violence Helpline.

Retrieved April 29, 2020, from The Hindu: https://www.thehindu.com/news/national/ncwlaunches-domestic-violence helpline/article31312219.ece.)

Domestic violence can be emotional, physical, economic, sexual or verbal. It also includes threats, name calling, controlling behaviours, abusing etc. During disasters or pandemics, the cases of domestic violence increase many times. (Gearhart S.et al, 2018). This can be due to many factors like financial loss, stress, alcohol addiction or lack of basic provisions. In low income group families, the unemployment of women due to lock down means financial dependence on spouse and no social support. Whereas in middle income families, domestic responsibilities and living in closed quarters can give rise to domestic violence. (Malathesh, B. C., Das, S., \& Chatterjee, S. S., 2020)

Women with disability, destitute, migrant labours are more vulnerable to these social challenges.

The women health care workers confronted some unique challenges of protecting their patients and themselves. They even met with a strange problem all over the world where they faced harassment, abuse and even violent attacks by people they were trying to help. (Green, L. et al, 2020)

\section{Need for change}

Despite the policies, plans made by the Government, the wide gap of gender disparity is clearly evident. The manifestation of this can be seen in social stereotyping, violence against 
women. The social and economic structure of the society is responsible for this inequality. After this pandemic, this social situation has become quite apparent and hence need for Women Empowerment has also become a relevant necessity.

\section{Ways of Empowerment}

On individual level:

Education: All these issues are very pertinent and in order to change these dynamics, the power equation between men and women should change. First step towards empowerment is education. Through education, people are able to differentiate between the right and wrong choices; it enables them to take decisions. Women should be able to take important decisions regarding themselves and their children. Education makes a woman capable to stand up for herself, makes her aware of her rights. It also leads to better educational opportunities for future generations and promotes better hygiene and health care facilities.

Economic Independence: Education leads to financial and economic development. A financially independent woman can face many adversities and challenges with courage. It gives her confidence and empowers her to take her decisions. It makes her strong and determined. She becomes self-sufficient and does not depend on anyone. She either contributes to the household income or runs it alone. She does not have to face any kind of violence by anyone; physical, economical, psychological or verbal. She becomes a role model for her children, and they understand the value of money and get inspired from her.

\section{On social level:}

Gender norms: The root of this gender disparity is the attitude of people, the roles assigned to the people according to their gender. These gender stereotypes ensure the status quo where women uncritically accept the roles assigned to them. Women are relegated to the unpaid care work. The responsibility of elders and children falls on the women whether she is employed or stays at home. At workplaces too, they endure discrimination. Female employees are paid unfair wages as compared to their male counterparts. They are not given equal opportunities for growth and face the glass ceiling. This oppression is due to society's devaluation of women's strengths, values and roles. Our society needs to adopt the culture of nurturance and cooperation.

Social action: Women can share their experiences with each other or in groups which will give them support and will help them in understanding the social context of their experience. Self -disclosure is therapeutic and healing. It will enable them in critically analysing the internalised messages and a sense of universalization. It will increase level of cohesion amongst women.

Socio-political Environment: The prevailing dysfunctional socio-political structure needs to be restructured. Even the Constitution of India not only mentions gender equality but also favours positive discrimination for women. Only making schemes like 'Beti bachao, beti padhao' is not sufficient. The safety and security of girls should also be ensured. 'One Stop Centre' is a good initiative for women but there is lack of awareness about it. More women should become part of judiciary, police department, government and should assume active roles in making and ensuring the implementation of laws. It will also help in reducing apathy towards crime against women. 


\section{CONCLUSION}

The ongoing COVID crisis has given us the opportunity to see the existing problems and bridge this gender divide. The age-old traditions and the norms should be reorganised. Gender roles should be redefined. Equal prospects should be made available to everyone. Women should actively help in empowering other women through education and employment. The power equation in the society should be restructured. With social transformation this is achievable. Nobody should face any kind of oppression, fear or threat. Equal and just society favours egalitarian relationships which in turn ensues a dynamic and sustainable society.

\section{REFERENCES}

Bhatia, A. 2020. "Women and COVID-19: Five Things Governments Can Do Now." UN Women News, March https://www.unwomen.org/en/news/stories/2020/3/newswomen-and-covid-19-governments-actions-by-ded-bhatia

Corey, G. (2013). Theory and Practice of Counseling and Psychotherapy (Vol. 9th ). Belmont, CA, USA: Brooks/ Cole.

Chandra J. 2020. NCW Launches Domestic Violence Helpline. Retrieved April 29, 2020, from The Hindu: https://www.thehindu.com/news/national/ncw-launches-domesticviolence-helpline/article31312219.ece.

Gearhart, S., Perez-Patron, M., Hammond, T. A., Goldberg, D. W., Klein, A., \& Horney, J. A. (2018). The impact of natural disasters on domestic violence: an analysis of reports of simple assault in Florida (1999-2007). Violence and gender, 5(2), 87-92.

Green, L., Fateen, D., Gupta, D., McHale, T., Nelson, T., \& Mishori, R. (2020). Providing women's health care during COVID-19: Personal and professional challenges faced by health workers.

Gururaj, G., Varghese, M., Benegal, V., Rao, G. N., Pathak, K., Singh, L. K., Mehta, R. Y., Ram, D., Shibukumar, T. M., Kokane, A., Lenin Singh, R. K., Chavan, B. S., Sharma, P., Ramasubramanian, C., Dalal, P. K., Saha, P. K., Deuri, S. P., Giri, A. K., Kavishvar, A. B., Sinha, V. K., Thavody, J., Chatterji, R., Akoijam, B. S., Das, S., Kashyap, A., Ragavan, V. S., Singh, S. K., Misra, R. \& NMHS Collaborators Group . (2016). National Mental Health Survey of India, 2015-16: Prevalence, pattern and outcomes. NIMHANS Publication. Google Scholar

How will covid 19 affect girls and young women? retrieved from https://planinternational.org/emergencies/covid-19-faqs-girls-women)

Lewis, H. 2020. "The Coronavirus Is a Disaster for Feminism: Pandemics Affect Men and Women Differently." The Atlantic, March19.

https://www.theatlantic.com/international/archive/2020/03/feminism-womens-rightscoronavirus-covid19/608302 [Google Scholar]

Malathesh, B. C., Das, S., \& Chatterjee, S. S. (2020). COVID-19 and domestic violence against women. Asian journal of psychiatry.

McLaren, H. J., Wong, K. R., Nguyen, K. N., \& Mahamadachchi, K. N. D. (2020). Covid19 and Women's Triple Burden: Vignettes from Sri Lanka, Malaysia, Vietnam and Australia. Social Sciences, 9(5), 87.

Power, K. (2020). The COVID-19 pandemic has increased the care burden of women and families. Sustainability: Science, Practice and Policy, 16(1), 67-73.

Shenoy, V., Mahendra, S., \& Vijay, N. (2020). COVID 19 lockdown technology adaption, teaching, learning, students engagement and faculty experience. Mukt Shabd Journal, 9(4), 698-702. 


\section{Why women empowerment is needed post COVID-19?}

Verma, S., \& Mishra, A. (2020). Depression, anxiety, and stress and socio-demographic correlates among general Indian public during COVID-19. International Journal of Social Psychiatry, 66(8), 756-762.

Wenham, C., J. Smith, and R. Morgan. 2020. "COVID-19: The Gendered Impacts of the Outbreak." The Lancet 395 (10227): 846-848. doi:10.1016/S0140-6736(20)30526-

2. [Crossref], [Web of Science $\left.{ }^{\circledR}\right]$, [Google Scholar]

\section{Acknowledgement}

The author appreciates all those who participated in the study and helped to facilitate the research process.

\section{Conflict of Interest}

The author declared no conflict of interest.

How to cite this article: Karulkar P. (2020). Why women empowerment is needed post COVID19? International Journal of Indian Psychology, 8(4), 712-716. DIP:18.01.089/20200804, DOI:10.25215/0804.089 